\title{
The Revolt against Reason: \\ Oswald Spengler and Violence as Cultural Preservative
}

\author{
Gregory Swer \\ University of KwaZulu-Natal \\ School of Religion, Philosophy and Classics, South Africa
}

\begin{abstract}
In The Decline of the West, Spengler argues that cultures have lifecycles. Although he warns that the end of Faustian (western) culture is nigh, Spengler suggests that the death of the culture might be forestalled if a rapprochement can be brought about between the technologized powers of Reason and the remains of cultural life. This portrayal of Reason as a salvific force seems to contradict Spengler's typical depiction of Reason as a violent anti-cultural force. This paper reconstructs Spengler's account of Reason as both killer and preserver of western culture and argues that in both roles it remains inherently violent.
\end{abstract}

Keywords: Oswald Spengler; The Decline of the West; Technics; Existentialism; Reason; Culture; Enlightenment; Violence; Civilisation.

\section{DOI: 10.22618/TP.PJCV.20204.1.201008}

The PJCV Journal is published by Trivent Publishing



This is an Open Access article distributed in accordance with the Creative Commons Attribution Non Commercial (CC$B Y-N C$-ND 4.0) license, which permits others to copy or share the article, provided original work is properly cited and that this is not done for commercial purposes. Users may not remix, transform, or build upon the material and may not distribute the modified material (bttp:/ / creativecommons.org/ licenses/by-nc/4.0/) 


\title{
The Revolt against Reason: Oswald Spengler and Violence as Cultural Preservative
}

\author{
Gregory Swer \\ University of KwaZulu-Natal \\ School of Religion, Philosophy and Classics, South Africa
}

\begin{abstract}
In The Decline of the West, Spengler argues that cultures have lifecycles. Although he warns that the end of Faustian (western) culture is nigh, Spengler suggests that the death of the culture might be forestalled if a rapprochement can be brought about between the technologized powers of Reason and the remains of cultural life. This portrayal of Reason as a salvific force seems to contradict Spengler's typical depiction of Reason as a violent anti-cultural force. This paper reconstructs Spengler's account of Reason as both killer and preserver of western culture and argues that in both roles it remains inherently violent.
\end{abstract}

Keywords: Oswald Spengler; The Decline of the West; Technics; Existentialism; Reason; Culture; Enlightenment; Violence; Civilisation.

\section{Introduction}

Oswald Spengler published the first volume of his two-volume The Decline of the West in Germany and Austria in the summer of 1918. Despite Spengler being a comparative unknown, and the imposing size and density of the book, it rose rapidly to the top of the bestseller lists and remained there for a number of years. Eight years after its initial publication it had sold over one hundred thousand copies. ${ }^{1}$ Published at the end of the First World War, just prior to Germany's defeat, it tapped into the public mood of despondency and loss of faith in the inevitability of progress that characterised the troubled period of the Weimar Republic. Its success provoked a furious intellectual debate, the so-called Spengler-Streit, between 1919 and 1922.

Spengler is generally taken to have been a philosopher of history who produced a highly speculative philosophical interpretation of world history. Spengler argues that world-history to date can be partitioned into the history of the growth and decline of eight (possibly nine) cultures. Using a technique that Spengler terms comparative morphology, he claims to have discovered that the life-history of a culture is analogous to the life-history of an organism, and that, like organisms, all cultures have a natural lifespan and a series of developmental stages (birth, growth, maturity, death) through which they must pass. So inevitable is the repetition of this pattern, that one who grasps the method of comparative morphology is able to determine in advance the future development of a culture-organism. ${ }^{2}$

\footnotetext{
1 H. Stuart Hughes, Oswald Spengler: A Critical Estimate (New York: Charles Scribner's Sons, 1952), 89.

${ }^{2}$ For an overview of the interpretations of Spengler's philosophy of history, see Gregory Swer, "Timely Meditations? : Oswald Spengler's Philosophy of History Reconsidered,"Prolegomena 17/2 (2018): 137154.
} 
Despite his commitment to a fixed process of growth, decline, death across all cultures, Spengler appears to hold out the possibility that the decline of western culture might be deferred, at least for a time. To understand Spengler's justification for this belief, one needs to understand the curious function that reason plays in Spengler's historical narrative. Reason appears in Spengler's early philosophy in a dual role, first as the serpent in the garden of culture, a mechanical, calculative form of cognition that kills the living forms of cultural existence, and second as a means of preserving the existence of western culture in its terminal, civilizational stage.

This paper will reconstruct the function of reason in Spengler's philosophy. First it will examine Spengler's account of the formation of reason in the development of cultural consciousness, and its appearance through the conceptual division of reality into the worldas-history and the world-as-nature. It will be argued that the origins of Spengler's critique of the deathly effect of calculative reason are to be found here, and can be traced from this point to his critique of enlightenment rationality. This paper will then explore the function of technology, and technological rationality, in Spengler's account of the character of civilisation, and the role of reason in the breakdown of cultural meaning in the civilizational stage of western culture's lifecycle. Finally, it will detail the role of technology, and reason, in Spengler's argument for the possibility of postponing the death of western culture. Spengler, I suggest, floats the possibility that the demise of the Faustian west could be held at bay for a time if a rapprochement could be effected between the forces of culture and the powers of modern technics. Whilst Spengler depicts such a rapprochement as an existential necessity, I argue that the 'overcoming' of reason that Spengler calls for is thoroughly imbued with violence and represents an exacerbation of the deathly tendencies of reason that he so vociferously condemned.

\section{The Origins of Consciousness}

Spengler offers us a genetic account of the development of reason as a response to the necessities of existence. This section will explore the ways in which reason, according to Spengler's philosophical anthropology, arose in response to the needs of the human organism in a pre-cultural state.

On Spengler's account, primitive (i.e. pre-cultural) humanity finds itself in a primal state of existential peril. Humanity is confronted with a tumult of unstructured sense experience and a set of alien powers that it intuitively senses lie behind these experiences. Gripped with what Spengler terms "world-fear," humanity is compelled to enumerate and then name the objects of its sensory field, and by doing so to structure and bring order to the contents of its experiential world. ${ }^{3}$ The effort of so doing propels human consciousness through a series of stages whereby it develops fundamental, and dichotomous, conceptual schema for representing its relationship to itself and the world-around. These include concepts of inner life and outer world, the possible and the actual, and space and time. ${ }^{4}$

It is the formation of space and time concepts, or Ur-symbol and Destiny as he terms them, that is most significant for Spengler. In a quasi-Kantian manner, they operate in his philosophy as the fundamental forms of intuition. It is on the basis of these forms of intuition, Spengler argues, that all the other experiential structures of consciousness found in the members of a culture are able to develop, and it is the spatial form of intuition in particular that gives human consciousness its unique cultural character. Subsequent to the appearance

\footnotetext{
${ }^{3}$ Oswald Spengler, The Decline of the West: Form and Actuality (New York: Alfred A. Knopf, 1926), 80.

${ }^{4}$ Gregory Swer, "Longing, Dread and Care: Spengler's Account of the Existential Structure of Human Experience," Journal of the British Society for Phenomenology 51:1 (2020): 71-87.
} 
of the Ur-Symbol and the related temporal form of intuition, all phenomena now present themselves to consciousness in the form of things-becoming or things-become, the potential and the living, or the actualised and the dead. In effect, Spengler suggests, the inhabitants of a culture find themselves living in two conceptual worlds, which he terms the world-as-history and the world-as-nature. These are the two "possible modes of understanding, of comprehending the totality of knowledge - becoming as well as things-become, life as well as things-lived - as a homogenous, spiritualised, well-ordered world-picture fashioned out of an indivisible mass-impression in this way or in that according as the becoming or the become, direction ("time") or extension ("space") is the dominant factor." "Spengler depicts the worldas-nature as the mechanical representation of the natural world as rationally cognised, abstracted from concrete historical reality and represented mathematically. The world-ashistory, on the other hand, is said to be the "organic logic" of human lived experience, the sense of the symbolic unity that underlies the diversity of human cultural life.

It is important to note that Spengler views the formation of these two worldviews as a common feature of all cultures, necessitated by the exigencies of existence. It is the world-asnature that hands a culture the means to order and control its environs. And although it is here that we see the birth of the 'cognising intellect,' and the seeds of the eventual rule of universalising reason, Spengler still holds that the development of the world-as-nature's mechanising worldview was necessary for the formation and continuation of a culture. In inception, for Spengler, reason serves cultural life. It should also be noted that whilst Spengler holds the development of forms of intuition of space and time to be universal features of cultures, and likewise the development of the world-as-nature and the world-as-history, he does not hold that there is any significant degree of similarity in the outcome of these developments. Each culture develops its own form of intuition of space, the Ur-symbol, and of time, and thus their own world-as-nature and world-as-history.

\section{The world-as-nature: Killing cognition and Existential Dread}

In this section I will explain in more detail the character of Spengler's world-as-nature, and the role of reason within it. In particular I will examine the ways in which the development of reason in this sphere is connected to conceptual violence, and the existential ramifications of this violence. Despite the decidedly negative treatment of reason in this context, I will suggest that Spengler holds that the operation of reason, for all its violence, still serves life.

With the formation of the world-as-history and the world-as-nature, the inhabitant of a culture finds themselves operating with a dualistic understanding of reality. On the one hand there is the world of organic existence, of possibility and change, and on the other the worldas-cognised, a static realm of mechanical causality. Spengler argues that the presence of these dichotomous conceptual schema call forth two fundamental existential feelings (Urgefühle), which he terms longing and dread. ${ }^{6}$ Longing, for Spengler, represents the desire of the inner (proper) to overcome the separation from the outer (alien), and to restore its lost unity. It directs the consciousness of the culture inhabitant towards the expression of their inner life through the realisation of the internal in the external world, and thereby towards praxis in the culture-world in which it finds itself. It is this fundamental longing, Spengler suggests, that gives the 'inner' world of humanity its ever-present intentional directedness towards the 'outer.'

However, this awareness of becoming (temporal existence), and the capacity to externalise and realise one's inner projects, in turn draws attention to the end point of becoming, namely

\footnotetext{
${ }^{5}$ Oswald Spengler, The Decline of the West: Form and Actuality, 55.

${ }^{6}$ Ibid., 78.
} 
the thing-become. And by doing so it prompts humanity to acknowledge the inevitability of its own eventual demise. This awareness of mortality elicits the second of Spengler's prime feelings, that of dread. Human consciousness, focussed on the actualising of the possible (the present and the future), is eventually obliged to confront the outcome, the actualised. "That which has happened is thenceforth counted with the become and not with the becoming, with the stiffened and not the living, and belongs beyond recall to the past." 7 The present no longer involves just the accomplishing of the possible, but the awareness of "a trickling-away" and "a passing." 8 t that moment where the proper gratifies its longing for the alien, mankind is simultaneously reminded of the inevitability of its own demise.

Here is the root of our eternal dread of the irrevocable, the attained, the final - our dread of mortality, of the world itself as a thing-become, where death is set as a frontier like birth - our dread in the moment when the possible is actualised, the life is inwardly fulfilled and consciousness stands at its goal. ${ }^{9}$

Time, with its terminal connotations, comes to be viewed as an alien power, a cause of worldfear, to be named and thereby contained. This dread of mortality drives the development and embrace of the timeless causal worldview of mathematical Nature, which seemingly exists outside the transience of the temporal. And yet this world-as-nature remains contingent upon the world of becoming (life), of boundless and infinitely fecund flux, which perpetually threatens to undermine efforts to contain it in the mechanical worldview of Nature. Spengler states that,

Becoming has no number. We can count, measure, dissect only the lifeless and so much of the living as can be dissociated from livingness. Pure becoming, pure life, is in this sense incapable of being bounded. It lies beyond the domain of cause and effect, law and measure. ${ }^{10}$

In addition to this, the existential security provided by the world-of-nature is itself problematic. The atemporal, static realm of Nature is a lifeless, deathly place. It is an ontological graveyard, a terminal world of things-become, which as it shields one from, also reinforces, the feeling of existential dread. Relief from the feelings of longing and dread is achieved through the actualising of soul, the "symbolising of extension, of space and things." The prime feelings, mediated by the culture's understanding of Destiny/Time and the Spatial Ur-symbol, are sublimated into transformative activity in the world-around, and given expression.

The fear triggered by the rationalising tendency of the world-as-nature thus stimulates productive activity, and thereby advances culture. And yet this fear also drives the extension of the world-as-nature, and the progressive treatment of all aspects of the world in a mechanical, deathly manner. And it is this imposition of the mechanical, and its attendant calculative rationality, onto all cultural life that ultimately kills culture. In this manner, the rise of reason within a culture both drives its development and erodes its foundations.

Discussion of the role of cognition in the development of the word-as-nature has remained thus far at a level of super-cultural generality. Whilst all cultures realise a world-ashistory and a world-as-nature, each does so in its own unique way. And, I argue, the purpose of Spengler's world-historical analyses was always to shed light on the nature and development of his own culture, that of the Faustian West. It is not the progressive

\footnotetext{
7 Ibid., 95.

8 Ibid., 79.

9 Ibid., 79 .

10 Ibid., 95.
} 
encroachment of the world-as-nature on all forms of western life that has brought about the crisis of technological modernity, on Spengler's account, but its combination with the uniquely western cultural mandate given by its Ur-symbol.

The Ur-symbol of Faustian culture Spengler describes as movement through "pure and limitless space". ${ }^{11}$ In contrast to the prime symbols of other culture-organisms, the Faustian is depicted as peculiarly dynamic. Whilst other cultures, such as the Egyptian or Chinese, have prime symbols that contain an idea of motion, they represent movement along a path between two fixed points. The Faustian, in contrast, represents endless movement towards the infinite. The Faustian Ur-symbol, along with its "derivatives"; Will, Force and Deed, give Faustian culture the dynamic trajectory that is inherent in its worldview and progressively expressed through its cultural forms. ${ }^{12}$ The western world-as-nature, and all the science derived from it, are amongst those cultural forms. The world-as-nature is governed by the a priori intuition of Space, the Ur-symbol, and consequently the natural world about which science theorises must be understood as the expression of a specific cultural worldview. Or as Spengler puts it, "Nature is a function of the particular Culture."13 And thus the Western scientific worldview, and its key concepts, are themselves expressions of the Faustian structuring of the world of extension, the Ur-symbol of infinite space. Space, rather than being a purely scientific term "is a spiritual something."."14

The world-as-nature is the attempt to render the world comprehensible and manipulable by means of "formula, law and scheme". ${ }^{15}$ Spengler states that, "The mechanism of a pure nature-picture, such as the world of Newton or Kant, is cognised, grasped, dissected in laws and equations and finally reduced to system." 16 The world of our experience is subject to "mechanical demarcation [emphasis removed]," a process whereby all that exists is reduced to its extensive properties and carved into discrete units. All relations are limited to those that can be represented in causal terms. Thus flattened and dismembered, the objects of the worldas-nature are ready to be further transformed into numerical symbols, abstract tokens of metaphysical devotion which are held to represent the true reality despite their great remove from lived experience. In this way the progressive reduction of all existence to a mechanical system serves western culture's Ur-symbol-given directive, to seek the infinite (in the form of the mathematical 'reality' underlying sensory experience) and the remove all obstacles to the movement of the Will. In other cultures at certain times, Spengler suggests, the world-asnature and the world-as-history exists in a state of dynamic tension. It is a hallmark of Faustian culture, of the embedding of the will-to-infinity in the world-as-nature, that it becomes a cultural priority to absolutise the mechanical worldview.

It is with the progressive encroachment of the world-as-nature into human social existence that Spengler marks the transition from living culture to dying civilisation. And, for Spengler, it is the Enlightenment that represents the highpoint of the rationalising project. Spurred by the successes of its sciences, and existentially threatened by the increasing mechanisation of the world-picture that accompanies those successes, systematic thinkers seek to bring all of human experiential existence under the rule of causal law. The unspoken yearning behind such efforts is to create a world beyond temporality, to fix rational order into human existence and then preserve that moment for all eternity. Spengler says, "our wakingconsciousness looks fearfully for a spell that will bind in the sense-world and overcome the

\footnotetext{
11 Ibid., 183.

12 Ibid., 337.

13 Ibid., 169.

14 Ibid., 183.

15 Ibid., 56.

16 Ibid., 56.
} 
death that cannot be evaded" and "we conceive causality as an anti-Fate, and make it create another world to protect us from and console us for this. And as the web of cause and effect gradually spreads over the visible surfaces there is formed a convincing picture of timeless duration essentially, Being, but Being endowed with attributes by the sheer force of pure thought." 17 Human consciousness, and the faculties of Reason and Will, become viewed as universal features, present and unchanging across all times and cultures. The Will, in the form of the $I$, becomes the foundation of all knowledge, and it refuses to acknowledge any limitations to its purview. Reason is brought to bear upon any and all forms of thought and ways of life. Religion, social hierarchy, life itself are no longer to be accepted and lived, but critiqued, dissected, and then rationally reordered and justified or else abolished.

Culture is the self-evident. The feeling of strangeness in these forms, the idea that they are a burden from which creative freedom requires us to be relieved, the impulse to overhaul the stock in order by the light of reason to turn it to better account, the fatal imposition upon the inscrutable quality of creativeness, are all symptoms of a soul that is beginning to tire. Only the sick man feels his limbs. ${ }^{18}$

Life ceases to be a given and becomes a problem to be rationally analysed and resolved. The distinction between culture and civilisation, "the living body of a soul and the mummy of it" as Spengler puts it, can be understood as a difference in the mode of existence. In culture one lives inwardly and unconsciously, in civilisation outwardly and consciously. As Herf correctly observes, for Spengler, "Conceptual understanding measures, divides, and thus "kills" the object it comprehends, whereas intuition fills the perceived object with soul and feeling." 19 And yet one cannot simply portray Spengler's position as soul/culture versus reason/civilisation for civilisation is just as much a part of culture as any preceding stage in the development of a cultural-entity. Even the culture-eroding forces of reason are themselves reflections of the culture's master-symbol and their triumph over all other ways of cultural being is likewise a fulfilment of its cultural imperative, the will-to-infinity.

That Spengler holds civilisation to be the death of culture is well known. The ways in which the seeds of this downfall were sown in the very first moments of cultural formation, and in which the forces of cultural destruction are themselves just as symbolic of the culture as the cultural forms they destroy, are less well known. And yet the death of culture in civilisation stems directly from the birth of the world-as-nature in the hazy days of that culture's birth.

\section{Technics and the Death of Culture}

Spengler observes that considered objectively the west's decline "comprises nothing less than the problem of Civilisation." 20 Spengler's purpose, I suggest, was to provide a philosophical analysis of a Western cultural crisis. Civilisations for Spengler represent the ultimate stage of a culture-organism's life-cycle. They are, he states,

the most external and artificial states of which a species of developed humanity is capable. They are a conclusion, the thing-become succeeding the

\footnotetext{
17 Ibid., 120.

18 Ibid., 353.

${ }^{19}$ Jeffrey Herf, Reactionary Modernism: Technology, culture and politics in Weimar and the Third Reich (Cambridge: Cambridge University Press, 1984), 53.

20 Oswald Spengler, The Decline of the West: Form and Actuality, 31.
} 
thing-becoming, death following life, rigidity following expansion... They are an end, irrevocable, yet by inward necessity reached again and again. ${ }^{21}$

As a culture enters the civilization stage it ceases to create and instead reinterprets and "remoulds all the forms of the Culture that went before, understands them otherwise, practices them in a different way." 22 The people of a pre-civilisational stage have an "unstrained mastery" over the symbolism of their culture, they bear it and actualize it without needing to cognize and analyse it. ${ }^{23}$ The people of a civilization lack this self-assurance and begin to feel these cultural forms as burdensome, to be subjected to rational scrutiny and reconstructed or replaced. In contrast to their cultural predecessors, the people of a civilisation live in a markedly self-conscious manner. Spengler contrasts the organism of culture with the "mechanism rising from hardened fabric" of civilisation. In the former, one lives 'inwardly' and Life presents a "settled conduct," an "instinctive morale." 24 In the latter, Life begins to appear problematic, and in need of theoretical representation and explanation. For Spengler, civilisation-man exists under the sign of space, rather than time, and must therefore think in its terms. As a consequence, in the present day, "only extensive possibilities are left." 25

From amongst Spengler's varied analyses in The Decline of the West, we may identify the following as common traits of the civilisational stage of a culture-organism. Firstly, spiritual/creative aridity, and the loss of a sense of self. Secondly, the dominance of a mechanical mode of thought and hyper-rationality. Spengler posits the above characteristics as general features of all cultures once they reach the civilizational stage of their development. Spengler's negative characterisation of civilization in general shares significant similarities with characterisations of the defining features of Western technological civilization put forward by numerous philosophical critics of modernity such as Jacques Ellul ${ }^{26}$, Herbert Marcuse ${ }^{27}$, Lewis Mumford ${ }^{28}$ and Jürgen Habermas ${ }^{29}$, each of whom emphasised the increasing dominance of technological rationality/instrumental reason over all other values in contemporary society. This suggests that it might be the case that Spengler's account of civilization, rather than being true of all culture-organisms, is in fact specific to Faustian technological civilization alone. In such a case, Spengler's 'Technics' would be equivalent to the terminal stage of modern Western culture-life.

Merlio suggests that the theme of technics is latent in Spengler's discussions of civilization. However rather than restricting it to Spengler's account of modern Western culture, Merlio argues that with Spengler technics should be understood as the key feature of the civilizational stage in all culture-organisms. He correctly points out that, "Without technics, there would be no world city, no massification, no comfort, no imperialism, there would be none of this simultaneous hedonistic and expansive materialism, respectively." 30 The civilizational stages of previous cultures would then be understood as technological modes of existence, albeit without the proliferation of technological devices and systems typical of Faustian

\footnotetext{
21 Ibid., 31.

22 Ibid., 351.

23 Ibid., 353.

24 Ibid., 354.

25 Ibid., 40.

${ }^{26}$ Jacques Ellul, The Technological Society, (New York: Alfred A. Knopf, 1964).

${ }^{27}$ Herbert Marcuse, One Dimensional Man, (London: Routledge Kegan Paul, 1964).

28 Lewis Mumford, The Myth of the Machine (New York: Harcourt Brace, 1967).

${ }^{29}$ Jurgen Habermas, Knowledge and Human Interests (Cambridge: Polity Press, 1987).

${ }_{30}$ Gilbert Merlio, "Spengler und die Technik," in Spengler Heute, ed. Peter Christian Ludz (Munich: Verlag C.H. Beck, 1980), 100.
} 
technological civilisation. Consequently, an analysis of Spengler's views on technology, understood here as a mode of existence rather than as artefacts, would amount to an analysis of his accounts of the civilizational stage in the development of a culture-organism.

However, there is more to Spengler's theory of technics than this. Leaving aside the more conceptual understanding of technics that operates in his account of civilisation, it is obviously the case that technics, understood as artefact and the body of knowledge necessary for its construction and use, can be found in the history of cultures prior to the civilizational stage. And, I will argue, an understanding of Spengler's account of the origins of such technics in the pre-civilisational stages of a culture's development is necessary if we are to fully grasp his theory of technics and his analysis of the unique nature and existential possibilities of modern Faustian culture.

\section{The Origins and Nature of Technics}

Spengler's account of the origins and nature of technics, like his account of the world-asnature, is inextricably connected with his account of the origins of human consciousness. Humanity's response to the question of its place in the macrocosm, according to Spengler, takes two key forms. With the first form humanity, the microcosm, seeks to comprehend the macrocosm and its purpose within it. To this end it constructs a coherent worldview capable of accounting for the world in which it finds itself. This first, theoretical, form manifests itself initially as myth, and then later as science. Humanity's second form of response is to act upon the environment, to constrain it, control it and transform it. This second, practical, form manifests itself initially as cult, then later as technics.

As humanity begins to order the world around by means of the elaboration of a system of signs, it employs technique for matters of 'how,' the material necessities of existence, and theory for the 'why,' the explanation of the "alien powers that loom, threatening in the dawn, behind the screen of sense phenomena." 31 As Spengler puts it, "Technique (technics) applies itself to visible near things and plain needs, theory to the distance and the terrors of the invisible." 32 Technics provides (limited) practical knowledge. Theory, on the other hand, drawing on technics, provides belief. Theory becomes myth and technics become cult. "The one teaches how to know the "numina," the other how to conquer them." 33 It is as a culture enters its later stages that scientific theory emerges from the religious. And as Merlio notes, as "science represents the profane and secular version of myth, so is technics the secular and rational form of the cult." 34 And yet for all of that, to Spengler they carry with them the indelible marks of their origins. "The image-world of physics remains mythic, its procedure remains a cult of conjuring the powers in things, and the images that it forms and the methods that it uses remain generically dependent upon those of the appropriate religion." 35

Consequently, if we consider technics as a cultural form in its historical entirety, it appears first as a form of praxis, in time becoming attached to religious myth as cultic ritual. As science begins to evolve out of religion, technics too sheds its outward religious aspect. As a culture begins to age and transform into its civilizational stage, the calculative, instrumental, mechanical methods and outlook hitherto typical of the technical-scientific outlook become apparent in other, previously unrelated fields, such as ethics and politics, and eventually become the dominant worldview and mode of organization and practice within that culture.

\footnotetext{
31 Oswald Spengler, The Decline of the West: Form and Actuality, 79.

32 Ibid., 395.

33 Ibid., 395.

34 Gilbert Merlio, "Spengler und die Technik," 102.

35 Oswald Spengler, The Decline of the West: Form and Actuality, 395.
} 
Thus, technics always begins as praxis and ends as the key aspect of a culture's civilizational stage. Furthermore, according to Spengler, in all cultures technical knowledge always precedes theoretical. It is, from the outset, an abstraction from technical praxis. As Spengler states, "in Nature the real aim is the winning of the material, and theory is only the servant of this purpose." 36

In order to identify that which Spengler holds to be culturally specific to Faustian technics we first need to establish what Spengler takes to be the dominant cultural attributes of Faustian culture. According to Spengler Faustian culture, like all other culture-organisms, has its own, unique Ur-symbol. Now Spengler at no point gives a definite account of what exactly the Faustian Ur-symbol is. Indeed, given his insistence that the truths that he wishes to impart must be intuitively seized, rather than rationally demonstrated, this is rather to be expected. However, he does provide a few imagistic descriptions that give the reader a sense of what he has in mind. It is "direction-energy which has an eye only for the most distant horizons,"37 "endless space," 38 "passionate Western [existence], roving in the infinite," 39 "pure and limitless space." 40

This yearning for the infinite, which might otherwise sound purely religious or metaphysical, has material dimensions. It manifests itself in the drive for complete knowledge of the cosmos, the overcoming of physical and conceptual boundaries, the instant and unresisted movement of the gaze out towards the farthest reaches. Frye insightfully summarises Spengler's conception of Faustian Ur-symbol as "a center with radiating points." 41 The value of this definition is that it does not just capture the outwards movement of the prime symbol towards the infinite, but the absolute centrality of the point of origin, that is, the ego, the willing subject. Spengler states that, "the Faustian is an existence which is led with a deep consciousness and introspection of the ego, and a resolutely personal culture evidenced in memoirs, reflections, retrospects and prospects and conscience." 42 In Faustian culture the ' $\mathrm{I}$ ' becomes "the world-centre for which everything else is world-around", a "centre of force." 43 The Ur-symbol represents "infinite extension," that is extension from the solitary ego of the Faustian individual, whether political, technological, economic, or spiritual, to the infinite. ${ }^{44}$

A concomitant of the Faustian urge for infinity is what one might call etherealisation. ${ }^{45}$ The Western compulsion to overcome all resistance to the extension of the Will is reflected in, amongst other things, the type of nature-picture that it constructs. Here the objects of our experience cease to be concrete individuals, as Spengler argues they were for Classical culture. Instead they are reduced to "unalterably-alike mass-points," represented mathematically and related to one another in a purely functional manner. ${ }^{46}$ The world-as-nature is symbolically constructed from and in accordance with the Ur-symbol from which it stems. Experience

\footnotetext{
36 Ibid., 153.

37 Ibid., 174.

38 Ibid., 188.

${ }^{39}$ Ibid., 203.

40 Ibid., 183.

${ }^{41}$ Northrop Frye, "The Decline of the West", Daedalus 103, No. 1, Twentieth-Century Classics Revisited (1974): 4.

42 Oswald Spengler, The Decline of the West: Form and Actuality, 183.

43 Ibid., 263.

44 Ibid., 308.

45 For a more detailed account of Spengler's notion of etherealization, see Gregory Swer, "Oswald Spengler and Martin Heidegger on Modern Science, Metaphysics and Mathematics," Idealistic Studies 47/ $1 \& 2$ (2017): 12-15.

46 Oswald Spengler, The Decline of the West: Form and Actuality, 377.
} 
itself, on which exact science depends, is an active structuring of the world in such a way that it serves the Will-to-Infinity. Objects, as obstacles to the willing subject, are named, mathematized and rendered insubstantial. They no longer stand over against the ego, but allow the free movement of the Will.

Moving now from the question of what is culturally specific to Faustian culture, to the question of what is culturally specific to Faustian technics, we find the same essential attributes. Namely, dynamic transformation, etherealisation, Will-to-Power, infinity-lust. Technics serves, and is a fundamental expression of, the Faustian Ur-symbol, the Will-to-theInfinite. "To battle against the comfortable foregrounds of life, against the impressions of the moment, against what is near, tangible and easy, to win through to that which has generality and duration and links past and future - these are the sum of all Faustian imperatives from earliest Gothic to Kant and Fichte, and far beyond them again to the Ethos of immense power and will exhibited in our States, our economic systems and our technics." 47

Faustian technics, like all other cultural forms of technics, has as its original purpose the 'winning' of the material. What is distinctive about it is the way in which this 'winning' is understood and the way in which the 'material' is structured in Faustian culture. To technics, whose common (trans-cultural) function is the extension of power over the material world, is added the 'ethos' of immense power and will, and the mechanical comprehension/ representation of nature. A, or perhaps, the originary source of power is put in the service of a culture whose raison d'etre is the Will-to-Power. This, for Spengler, is the essential reason for the incredible novelty of technological development in Faustian culture, for the radical technological transformation of the world and human existence. In this sense technology (as both worldview and material apparatus) has always been the goal of the Faustian cultural project. And seen in this light, Faustian technical civilization represents then not just the hardening, terminal stage of a culture, but also the culmination of the Faustian project penetration to the infinite and the absolutisation of the Will-to-Power.

It is only once we have grasped this point that we can discern what I would argue is the true purpose of Spengler's analysis. Not the rejection of technological modernity in favour of an earlier, better cultural stage, or in anticipation of the arrival of a new cultural structure. Neither option is a viable possibility on Spengler's account. For Spengler, the real problem besetting technological civilization lies in its alienation from its own technics. Faustian humanity is in danger, in its unfettered pursuit of knowledge and power, of losing itself to a technical imperative. Having restlessly developed the technological means to complete the dynamic trajectory of the Faustian Ur-symbol, Western humanity has lost sight of the cultural reason that lay behind this development. Having forgotten the end of technological development, humanity now looks to technological products for purpose or ceases to look at technology at all. Some come to view technological development as the end in itself, others seek purpose in the revival of dead or dying cultural forms, or metaphysically opaque borrowings from other cultures. In short, for Spengler, Faustian humanity has become alienated from its own cultural project at the very moment of its culmination.

The question then arises of how this estrangement came about and how Spengler thinks it can be rectified. What has changed in the technological project of Western culture? And this in turn raises the question of how Spengler now understands the nature of technology in Faustian modernity.

${ }^{47}$ Ibid., 315. 


\section{Existential Technics}

We can now consider the ultimate purpose of Spengler's early philosophy. Having analysed the existential condition of modern Western humanity, its intrinsic connection to and current alienation from technics, Spengler can now move from description to prescription. Spengler states that

The West-European, however historically he may think and feel, is at a certain stage of life invariably uncertain of his own direction; he gropes and feels his way and, if unlucky in environment, he loses it. But now at last the work of centuries enables him to view the disposition of his own life in relation to the general culture-scheme and to test his own powers and purposes. ${ }^{48}$

Here, in a nutshell, is the twofold purpose of Spengler's comparative account of the course of world-history in terms of the waxing and waning of isolated culture-organisms. It is intended to make Faustian humanity consider the state of its own life and actively reflect upon its potentialities and capacities for future action. It is, in other words, an existential assessment of the condition of civilizational humanity intended to bring about an existential decision regarding the future course of Faustian culture.

From the vantage point of a late-life, Faustian humanity is able to employ the considerable historical knowledge accumulated over its lifespan to consider its present situation in relation to the overall trajectory of its culture. In doing so, it finds itself on the very verge of fulfilling the Faustian project: to see through all material and conceptual encumbrances and to grasp the foundations of all reality. For Spengler, as we have seen, human investigation cannot penetrate beyond the realm of phenomena and all metaphysical systems that claim to do so are in fact heuristic ordering strategies of a purely instrumental nature. Thus, the investigation into the foundations of reality becomes an investigation into the foundations of human knowledge of reality, and the conditions of its possibility. In other words, Faustian humanity finds itself confronting itself. The Faustian project to uncover the ultimate truth of existence finds itself at the end of its quest at the same point from which it began at the birth of Faustian culture.

The search for the secrets of the ultimate ends with the discovery that one cannot escape the horizon of one's own subjectivity. And yet for Spengler whilst this outcome might be ironic it is not altogether tragic. Although the endpoint of the Faustian project was not the one anticipated at the outset, for Spengler its attainment represents an enormous advance in human knowledge. Faustian humanity, according to Spengler, is in the historicallyunparalleled position of grasping the contingent nature of all knowledge and the cultural parameters of human existence. And with the benefit of this historical hindsight one can view the entirety of the history of Faustian culture as a cohesive development in that, beneath the flux and change, one can now discern the progressive expression of the Faustian Ur-symbol.

This historical awareness has two main implications. Firstly, by viewing the history of Faustian culture as a developmental whole, late Faustian humanity is in a position to recognize the existence of the Ur-symbol and its role in the structuring and historical/symbolic development of Faustian culture. Whilst previous generations of Faustians 'knew' the Ursymbol in that they expressed it in their works and furthered its cultural articulation, the inhabitants of Faustian civilisation are the first to know the Ur-symbol in a self-conscious manner. They are capable of recognizing the cultural a priori as both (culturally) necessary and (historically) contingent. They are capable not just of being directed by the Ur-symbol but of being aware that they are being so directed.

${ }^{48}$ Ibid., 40-41. 
The second implication of Faustian civilisation's newfound historical awareness is that it is able to grasp its historical location. An overview of the sweep and underlying meaning of the history of Faustian culture is a possibility for the inhabitant of Faustian civilisation purely because of their temporal position at the waning of Faustian culture. The owl of Minerva, for Spengler too, only spreads its wings with the falling of dusk. The philosophical knowledge gained of the cultural structuring and limitation of the possibilities of human experience by historical hindsight does not confer the power to alter these structures or limits, or reverse the aging process whereby a culture progressively exhausts its expressive potential. Spengler states that, "It will not be - already it is not - permissible to defy clear historical experience and to expect, merely because we hope, that this will spring or that will flourish." ${ }^{49}$ The ability to articulate the nature and role of the Ur-symbol in Faustian history is only possible because that history is drawing to a close. In this way, the ability to discern the pattern beneath the history of Faustian culture points back to the location of the observer's vantagepoint at the end of history.

A genuine acknowledgment of one's current, civilizational age as the last stage of Faustian culture, for Spengler, must necessitate a fundamental re-evaluation of one's existential situation. With the aging of a culture-organism, Spengler argues, comes a progressive diminishment of symbolic creativity and existential possibilities. He states that, "The present is a civilized, emphatically not a cultured time, and ipso facto a great number of life-capacities fall out as impossible." ${ }^{50}$ This, he suggests, is due both to a general diminution in cultural expressive energy and to a resulting restriction of the fields of human praxis in which symbolic creativity remains a viable option. Faustian civilisation's new insight into history reveals that genuine creativity lies in the expression of the cultural imperative of the Faustian Ur-symbol. More specifically, genuine creativity involves expression of that imperative in a manner appropriate to the current cultural mood (early, mature, etc.). As a consequence, those who seek to express genuine cultural creativity should seek to do so in those few domains in which creativity is still possible, and to do so in manner consonant with the late civilizational mood.

Spengler is quite clear about which fields he believes still possess creative potential. $\mathrm{He}$ states that "politics, technics or economics" are the only areas of cultural activity that do not exhibit "the common symptom" of decline. ${ }^{51}$ These fields, for Spengler, are those that are most dependent on the exercise and development of technique as an end in itself. Technics, unlike science, requires no accompanying metaphysics and thus does not feel the drag of the culture-wide decline in such innovation. Its attitude to the theories of science that it employs in its activities, for Spengler, was always pragmatic and instrumental. The symbols were calculative conventions and conveniences rather than figures of metaphysical import. Application is the key with technics, rather than truth, on Spengler's account. And the purpose of technical activity according to Spengler is the same as that of economic and political activity. Namely, the pursuit of power for its own sake. Or to be more specific, the pursuit of power in order to secure the means to acquire more power. This being so, the only options such fields of activity can offer will necessarily be extensive ones. Hence Spengler's statement that for the people of Faustian civilisation "only extensive possibilities are left to them." 52

One might concede the validity of Spengler's civilizational analysis and yet still insist that the fact that economics, technics and politics are the last remaining areas of creative praxis does not by itself constitute a compelling reason for pursuing these activities. Why, one might

\footnotetext{
49 Ibid., 40.

50 Ibid., 40.

51 Ibid., 425.

52 Ibid., 40.
} 
ask, should one not choose painting, or music as one's life's work, regardless of whether its creative heyday is behind it? Spengler's answer appears to be because such a decision, in the face of the knowledge of the lateness of the hour and the restriction of 'life-capacities,' would be historically myopic, wilfully self-deluding and 'care-less,' or inauthentic.

For Spengler, one cannot rewind the aging of a culture-organism. A form of life that is appropriate at one stage in the lifecycle of a culture, is no longer possible at a later stage. In a field of human activity, such as art for example, the end of its creative potential does not mean a diminution in artistic creativity but its cessation. The capacity of that form to articulate the cultural imperative, which for Spengler is the fundamental characteristic of all forms of human activity, is exhausted. All that is left to the civilisation-artist is a cultural boneyard of now defunct forms and symbols. Spengler states that, "The final result is that endless industrious repetition of a stock of fixed forms... all is patternwork." 53 One can rearrange the bones into new patterns but one cannot breathe new life into them. In addition to this Spengler notes that the purpose of art changes as it atrophies. "Art itself becomes a sport (hence the phrase "art for art's sake") to be played before a highly-intelligent audience of connoisseurs and buyers." ${ }^{4}$ No longer is art's purpose to express the inexpressible, the nature of the Ur-symbol. Rather its purpose is the intellectual gratification of an artistic elite and commercial profitability. With the historical hindsight of civilizational existence, Spengler suggests, the artistically-minded individual cannot pretend to themselves or to others that their activity is anything other than this. And so too with most other forms of life in Faustian civilisation. To choose them is, for Spengler, to willingly choose to be inauthentic.

Late cultural life, such as one finds in Faustian civilisation, is for Spengler one that is (or at least ought to be) without illusions. The symbols that permeate the culture-world are seen to be without content, and are grasped purely in terms of their heuristic value. Faustian culture, in its last years, arrives at the conclusion that Vaihinger urged in his Philosophy of 'As If,' namely that symbols be recognized as useful fictions and accepted as such, as features of our subjective ordering of the phenomenal world as not as objective descriptions of reality. Spengler tells us that, "Pure Civilization, as a historical process, consists in a progressive taking-down of forms that have become inorganic or dead." 55 The civilizational stage as Spengler describes it is one of Vaihingerian enlightenment in which metaphysics of all sorts are discarded.

Faustian humanity then finds itself in an existential quandary. With the exhaustion of most forms of cultural expression and the recognition of the fictional (in the sense of contingent and practical) nature of most cultural 'truths' and 'meanings,' the individual Faustian finds itself surrounded by 'things,' entities that have lost their symbolic content. Civilisation "begets no more, but only reinterprets, and herein lies the negativeness common to all periods of this character." 56 These 'things' no longer offer a means of expressing the individual's lived experience, nor of giving that lived experience any sense of a greater purpose. As Spengler puts it,

Faustian man has nothing more to hope for in anything pertaining to the grand style of Life. Something has come to an end. ${ }^{57}$

The dynamic sense of existence which typified Faustian culture requires an end, a telos, and this is exactly what civilizational humanity finds itself without.

\footnotetext{
53 Ibid., 295.

54 Ibid., 36.

55 Ibid., 32.

56 Ibid., 351.

57 Ibid., 363.
} 
$[\mathrm{N}]$ othing remains but the mere pressure, the passion yearning to create, the form without the content. This soul was Will and nothing but Will. It needed an aim for its Columbus-longing; it had to give its inherent activity at least the illusion of a meaning and an object. ${ }^{58}$

And this need for a telos, Spengler suggests, is still felt.

Without a living symbolic structure to give form and purpose to its existence, Faustian civilisation finds itself in a fundamental state of disorder. The people of Faustian civilisation are "a new sort of nomad, cohering unstably in fluid masses." ${ }^{9}$ Lacking forms of life, they themselves are without form, internally and externally. Materialistic, with "keen and cold intelligence," the ethos of Faustian civilisation, if one can still use the term meaningfully in this context, is one of frantic and superficial "busyness'. ${ }^{60}$ Instead of "style" one finds "taste," instead of "form" one finds "fashion." "The inward necessity is no longer there, there are no longer 'schools,' for everyone selects what and where it pleases him to select." 62

Spengler's comment refers to art, but applies to most cultural activities. Faustian civilisation is a loose aggregate of "industrious cobblers and noisy fools, who delight to produce something for the market, something that will "catch on" with a public for whom art and music and drama have long ceased to be spiritual necessities." 63 Its society, feeling the need for form, rapidly creates and briefly coalesces around transient fads, the illusions of living forms of life. And yet, these forms, being calculative, mechanical reiterations of bygone structures, have no claim upon the inner life of Faustian humanity. They are external attempts to sate an internal craving, and as such treat "thinking and feeling and forming as industrial art." 64 As such they offer only fleeting, unsatisfactory respite from Faustian humanity's need for meaning.

A second way in which Faustian humanity responds to civilisation's radical disenchantment of the world, Spengler suggests, involves a turn to religiosity. Faustian culture

loses its desire to be, and, as in Imperial Rome, wishes itself out of the overlong daylight and back in the darkness of protomysticism, in the womb of the mother, in the grave. The spell of a "second religiousness" comes upon it... ${ }^{65}$

The inhabitants of Faustian civilisation find themselves increasingly alienated in a world in which the mastery of technique has gone hand in hand with "the collapse of symbolism." 66 Faustian modernity is, in Spengler's depiction, mechanical in character. Its human parts are deracinated, rootless and homogenous. The motions of society are carefully calculated and essentially repetitive, an industrious reworking of dead material. The mood of the cities is frenzied, an artificial vitality intended to create the illusion of life. The only meaning or value still to be found in the welter of desymbolised objects that surround Faustian humanity is, for Spengler, a monetary one. And pecuniary value is "an inorganic and abstract magnitude." 67 As such it cannot satisfy the Faustian denizen's need for meaning, for an inner life that

\footnotetext{
58 Ibid., 363-364.

59 Ibid., 32.

60 Ibid., 33.

61 Ibid., 197.

62 Ibid., 197.

63 Ibid., 293.

64 Ibid., 294.

65 Ibid., 108.

66 Ibid., 420.

67 Ibid., 33.
} 
signifies through its expression in praxis. In response to an outer world which they no longer shape, one that has become wholly alien, some turn to a fervent reworking of old religious tropes. Its appeal, Spengler suggests, lies in its attempt to bridge the now horrifying gulf between inner and outer, proper and alien by recreating a primitive religious state in which inner and outer are not yet separated. However this religion, and its pseudo-symbolics, are not capable of generating new cultural meaning. The 'second religion,' in this respect, is very much a part of the late cultural stage that it wishes to overcome. It too can only play with dead forms of what was once living. Spengler states of civilizational man that

Bitterly as he may feel the inner emptiness and poverty, earnestly as he may long to be religious, it is out of his power to be so. All religiousness in the Megalopolis rests upon self-deception. ${ }^{68}$

For Spengler all cultural life is, in a sense, religious. Religion, as a specific form of activity, derived its expressive power from its connection to the fundamental symbol of the culture. Cut off from that source religion, like art, is dead. The turn to religion then is but another form of 'self-deception.' It too is, for Spengler, a 'care-less,' inauthentic response to the cultural crisis.

Indeed, I would argue that Spengler's depiction of civilisation as a whole is one that portrays it as thoroughly inauthentic. Its religious yearning for past certainties, its endless recycling of defunct symbolic forms, and its present-centred fixation on the new, the faddish, the ephemeral, are all symptoms of a culture that is in denial of its own temporality. It is interesting to note that for Spengler, despite his conservative political affiliations and frequent depiction as a reactionary, the pull of the past on the consciousness of the present is nearly always regressive. His focus on history in The Decline of the West was intended to outline the structures of Faustian existence, and to confront Faustian humanity with the reality of decline and the death of the symbolic. Spengler's use of history is present-centred. His critique of late Faustian modernity was not intended to provoke despair or fatalism, but to facilitate the sloughing off of dead historical forms of life. In other words, Spengler's history was intended to free Faustian civilisation of the burden of the past.

With Spengler, as with Vaihinger, the recognition of all symbols as fictions does not detract from their utility. However, for Spengler neither this recognition, nor the accompanying discarding of the metaphysical import of the symbolic, in any way undermines the reality of care as the fundamental structure of Faustian existence. The religious attempt to recapture the past experience of symbolic unity, and the frantic triviality and immediacy of civilizational life, are for Spengler denials of temporality. Religious revivalism is not an acknowledgment of the presence of the past in the present, but the denial of the present. And the present-centredness of Faustian civilisation imagines the future as a continuous unchanging 'now.' Both lack the sense of futurity that is integral to care-full existence in that both religiosity and secular cosmopolitan modernity evade the necessity of recognising their existential possibilities and choosing from among them. And Spengler's technique for forcing Faustian civilisation to acknowledge its futurity is to confront it with its imminent death.

Death, in the sense of cultural death as opposed to personal death, operates for Spengler in a manner rather similar to that of Karl Jaspers' concept of a boundary or limit situation. ${ }^{69}$ Boundary situations, on Jaspers' account, are moments in human existence when one is confronted with the actuality of one's finitude. They represent a boundary to one's existence which cannot be avoided and beyond which one cannot fathom. They have the effect of forcing the individual to confront the existential dimension of their lives. The awareness of

68 Ibid., 409-410.

${ }^{69}$ Karl Jaspers, Philosophy Volume 2 (Chicago: Chicago University Press, 1969). 
death as an inevitable outcome is, for Jaspers, the ultimate boundary situation. Death, in addition to being unavoidable, is also unalterable by objective means. Faced with death as a boundary situation, the individual can (if they choose) be brought to reflect upon the limitations of their physical existence and the importance of confronting the existential implications of their own death. In such a moment one experiences what Jaspers terms foundering (Scheitern), a loss of old securities and a feeling of existential Angst, and is forced to face up to the situation and to come to terms with it. As Peach puts it, for Jaspers, "[f]acing up to boundary situations, then, indicates accepting, enduring and coming to terms with one's particular extreme situation."70 The Angst that results from recognition of one's own mortality and eventual passage into non-being can be debilitating, but for Jaspers it can also be a source of resolve and courage. He states that, "we become ourselves by entering with open eyes into the boundary situations." 71

Similarly with Spengler, the awareness of one's historical location in the dying stages of a culture-organism forces one to consider the existential implications of a late life. For all the enormous power of contemporary technics and the ratiocinative calculation of contemporary humanity, Spengler suggests, the fact of cultural death cannot be altered. It is a non-negotiable feature of Faustian culture. This existential confrontation with the impending death of Faustian culture, for Spengler, reveals to Faustian humanity the fundamental structures of their experiential existence. It points back to the fundamentality of care and the central role of the Ur-symbol in Faustian existence. It reveals the inward necessity to construct meaning for oneself and the culture-world, and simultaneously the inability of mundane civilizational actuality or religiosity to provide an existential substitute for the lost telos of the Ur-symbolderived cultural imperative.

It should be noted that on Spengler's account this loss of telos does provide, by way of compensation for the existential Angst it occasions, the gift of absolute clarity regarding the nature of the culture-world, the cognition (not feeling) of the world as a unified symbolic whole. This latter point is extremely significant. Faustian humanity is in a position to know its history, to grasp its fundamental meaning and thus understand the course of development it has taken. They are able to do this because it is dead, a thing-become, and thereby capable of being cognized. Consequently, the late Faustian is able to perceive retrospectively that the verities and certainties of their current way of life, particularly the hegemony of mechanical rationality and technological power, are not timeless truths but the consequences of the preceding historical stages of Faustian culture. Spengler states that

Scepticism is the expression of a pure Civilization; and it dissipates the worldpicture of the Culture that has gone before. For us, its success will lie in resolving all the older problems into one, the genetic. The conviction that what is also has become, that the natural and cognizable is rooted in the historic, that the World as the actual is founded on an Ego as the potential actualized, that the "when" and the "how long" hold as deep a secret as the "what," leads directly to the fact that everything, whatever else it may be, must at any rate be the expression of something living. Cognitions and judgments too are acts of living men. ${ }^{72}$

Questions of eternal truth and the nature of reality in Faustian civilisation, Spengler suggests, are seen to be in actuality 'genetic' questions. The issue is no longer how our

\footnotetext{
${ }^{70}$ Filiz Peach, Death, "Deathlessness" and Existen₹ in Karl Jaspers' Philosopby (Edinburgh: Edinburgh University Press, 2008), 65.

${ }^{71}$ Karl Jaspers, Philosophy Volume 2, 179.

72 Oswald Spengler, The Decline of the West: Form and Actuality, 45-46.
} 
knowledge claims access or uncover reality, but how the structure of those knowledge claims derives from those that precede it and how all such epistemological structures derive their authority from the fundamental symbol of Faustian culture. The causal-mechanistic mode of world perception then appears as but a late cultural manifestation, a form of life, as contingent and symbolic as those that it displaced, and equally dependent upon the Faustian Ur-symbol.

In addition, the loss of meaning and sense of alienation experienced by civilisational humanity is now understood as something that did not befall Faustian culture from the 'outside.' The impoverished inner life of Faustian humanity was not caused by the desymbolised world of material things that surrounds it, but rather was itself the cause of that world. For Spengler, the perspective of the reason-dominated inhabitant of Faustian civilisation is what Huizinga terms a "Medusa-look at the world." 73 The world, and Faustian humanity itself, were increasingly detached from life and conceived as things-become. Existence came to be perceived mechanistically and they expressed this view of the world-asnature by symbolically transforming their environs to reflect this outlook. Scheler summarises Spengler's insight, saying that the Faustian

objectifies the always deficiently filled emptiness of his own heart into an infinitely empty being and allows this emptiness to precede things and their causal relation. ... it is his own "nay," the emptiness of his own heart, which yawns before him seemingly from the outside and awakens the dread which Pascal so frighteningly depicted... ${ }^{74}$

The crisis of civilisation is thus of civilisation's own making. This would be a grimly ironic final comment on Western civilisation if not for the fact that Spengler holds that this crisis also offers an opportunity.

In the clarity of civilisation's harsh light, the causal-mechanistic 'truths' won by science appear as empty symbols with only instrumental value, and all symbols can be traced back to the basic structures of the Faustian culture-world. However, for Spengler, with this sceptical insight comes simplification and affirmation. Shorn of metaphysical trappings and reduced to abstract symbols and formulae, the profusion of Faustian culture's symbolic outpourings over the course of its history can be seen to be a series of iterations of the same symbolic pattern, attempts to express the same fundamental idea.

The mark of the great crisis is its innumerable passionate questionings and probings. In our own case there were books and ideas by the thousand; but, scattered, disconnected, limited by the horizons of specialisms as they were, they incited, depressed and confounded but could not free. ${ }^{75}$

However, when viewed with the historically-informed scepticism of Faustian civilisation we can see that, despite the symbolic profusion, "[t] he tasks before men were not, as supposed, infinitely numerous - they were one and the same task."76 All symbolism relates back to the prime symbol. And even stripped by rational critique of their claims to universal truth, the symbolic structures of fields of activity like the sciences still retain their instrumental utility. Civilisational scepticism then reduces the symbolic field and lets what remains stand forth as what it essentially is, a heuristic contrivance of practical efficacy.

\footnotetext{
73 Johan Huizinga, "Two Wrestlers with the Angel”, in Dutch Civilisation in the Seventeenth Century (London: Collins, 1968), 164.

${ }^{74}$ Max Scheler, Selected Philosophical Essays (Evanston: Northwestern University Press, 1973), 336-337.

75 Oswald Spengler, The Decline of the West: Form and Actuality, 47-48.

76 Ibid., 48.
} 


\section{The Existential Necessity of Engineering}

For Spengler, the inhabitant of Faustian technological civilisation is beset by existential Angst that derives from the ascendancy of rational-calculative forms of thought and life and the loss of form-giving meaning that accompanied the overcoming of metaphysics. The yearning for the infinite that characterised the Faustian cultural imperative has led to a confrontation with its own contingency, limitation and finitude. The shared sense of the imminent demise of Faustian culture serves to remind Faustian humanity of its fundamental existential need for meaning and purpose, and expressive praxis, whilst simultaneously reinforcing the necessity of doing so immediately. Faustian humanity feels the need for meaning and yet finds itself incapable of creating new illusions to mitigate the ultimate meaninglessness of their activities. The fundamental structure of its existence, care, calls it to acknowledge its futurity and choose to give its existence meaning, and yet it appears to lack the creative resources to do so.

Spengler however maintains that Faustian civilisation, spiritually emaciated though it may be, still has some potential for the creation of meaning, and with it the formation of an existential project. To do so will require the Faustian individual to recognise their location in the terminal stage of their culture and to size up its last possibilities without self-deception or wishful thinking. It will involve what Spengler terms "stock-taking," a pragmatic tally of the remaining resources of Faustian culture. He writes

Our scepticism is not an attack upon, but rather the verification of, our stock of thoughts and works. It confirms all that has been sought and achieved for generations past, in that it integrates all the truly living tendencies which it finds in the special spheres, no matter what their aim may be. ${ }^{77}$

Civilisational scepticism, for Spengler, does not negate the accomplishments of Faustian culture through abandoning its metaphysical claims to truth. On the contrary, it affirms the enormous power that has been granted by means of its symbolic fictions and artificial contrivances. The awareness of the 'genetic' history of Faustian culture shows the utility of each fabrication, material or ideational, in expressing the cultural imperative in accordance with the governing mood of the age and in serving the needs of life. By stock-taking Faustian civilisation is to assess what utility-potential remains in its fabrications and how they might be made serve the needs of their current civilizational mood.

It is this latter point that is of particular significance at this juncture. A tally of the instrumental capacities of Faustian civilisation cannot, by itself, enable Faustian humanity to give their existence a purpose. The fundamental Faustian feeling of care requires a living/becoming form of life. One cannot after all have an authentic relationship to one's own futurity in a world of things-become. Here I would refer back to Spengler's point that the purpose of the stock-taking was also to take account of Faustian culture's remaining 'living tendencies.' Spengler, it transpires, does not think that the creative fires of Faustian culture have yet been completely extinguished. The solution to Faustian humanity's existential need for a telos, according to Spengler, lies in its technology.

Spengler follows Vaihinger in asserting that praxis precedes theory. Accordingly technics, on Spengler's account, precedes science in terms of its historical development. It appears as a collection of 'technical rules,' to use Vaihinger's term, gathered from general observation of everyday regularities in nature. Or as Spengler puts it, humanity evolves "from the small everyday experiences an image of Nature which contains the sum of technical indications observed as recurrent." 78 Spengler's explanation of what he means by recurrent technical

\footnotetext{
77 Ibid., 48.

78 Ibid., 395.
} 
indications is rather opaque, but what he seems to mean are repeated phenomenal patterns. Technics in its originary form, for Spengler, seems to involve what Vaihinger called "registering, analysing and systematically establishing those technical operations and manipulations which are the most frequent, regular, and important." 79 Its operations are straightforward and employ "instantly-comprehending technique [Technik]."

From the examples from the animal world that Spengler provides, such as the hunting eagle and the grazing deer, technics from its outset served a purely practical purpose of catering for the exigencies of bodily existence. It "applies itself to visible near things and plain needs." 81 It represents a purely instrumental mode of praxis intended at extending human power over its circumstances. Theory, which appears after technics, is for Spengler religious in origin and involves first a mythological component, for the elaboration of a metaphysical schema capable of accounting for "the distance and the terrors of the invisible." 82 To the myth is then added the cult, which attempts to summon and control the metaphysical forces of the myth. It is the theory that, according to Spengler, evolves into science. And, Spengler argues, science remains as metaphysically inclined as the religious mythology and cult from which it emerged.

The significance of this is that technics, in comparison to science, never had any overt metaphysical content or objectives. Its function, then as now, was the practical extension of human power. Consequently, the desymbolising that occurs in Faustian civilisation has little impact upon technics given that its attitude to the symbols of science, or any other field, was always instrumental and pragmatic. The rationalising civilizational scepticism which Spengler claims leads to the viewing of all symbols as practical fictions with no correspondence to metaphysical reality thus represents an expansion of the technical worldview to the entire culture-world.

This is not to suggest that Faustian technics operates at a complete remove from the symbolic structures of the culture-world. As Vaihinger points out, a mechanism (whether ideational or material) "is not intelligible without a knowledge of the purpose it serves." 83 Faustian technics accordingly must be understood as a body of techniques developed to facilitate the purposes of Faustian life. The needs of Faustian humanity, as their culture grows more complex, move beyond simple physical sustenance and involve certain existential necessities, namely the expression of the Ur-symbol. In this way, Faustian technics has always served the symbolic needs of its culture without ever being dependent upon them for its operation. And this is the reason why for Spengler technics as a form of praxis remains potent in the post-metaphysical environment of Faustian civilisation.

Despite this instrumental detachment from the now defunct symbolic structures of late Faustian culture, Spengler suggests that technics possess a vital connection to the Ur-symbolinspired cultural imperative. Technics, on Spengler's account, serves to enhance the power of a culture to pursue its cultural objectives. The imperative of Faustian culture is the extension of the Will, its mastery over the phenomenal. It is the "adamantine will [my emphasis] to overcome and break all resistances of the visible". ${ }^{84}$ Technics seeks to increase power. The Faustian Will wills more power. In this way, for Spengler, Faustian technics are distinct from the forms of technics in all other cultures. In other cultures, technics serves the Ur-symbol as a means to an end. Whereas Faustian technics, far more than Faustian art or music or religion,

\footnotetext{
${ }^{79}$ Hans Vaihinger, The Philosophy of As If (London: Kegan Paul, Trench, Trubner \& Co., 1935), 10.

80 Oswald Spengler, The Decline of the West: Form and Actuality, 395.

81 Ibid., 395.

82 Ibid., 395.

${ }^{83}$ Hans Vaihinger, The Philosophy of As If, 70.

84 Oswald Spengler, The Decline of the West: Form and Actuality, 185-186.
} 
represent the purest expression of the Ur-symbol of Faustian culture in that they represent both the means to an end, and the end itself.

For Spengler then it is the engineer, rather than the philosopher or artist, who now creatively expresses the Faustian cultural ethos. The engineer, Spengler tells us, still does something "that is true and real" rather than "chew over once more the old dried-up themes." 85 For all his emphasis on the instrumental, non-conceptual nature of technics, Spengler also stresses the aesthetic, formative power of modern technics. He states that

I would sooner have the fine mind-begotten forms of a fast steamer, a steel structure, a precision-lathe, the subtlety and elegance of many chemical and optical processes, than all the pickings and stealings of present-day "arts and craft," architecture and painting included. I prefer one Roman aqueduct to all Roman temples and statues. I love the Colosseum and the giant vault of the Palatine, for they display for me to-day in the brown massiveness of their brick construction the real Rome and the grand practical sense of her engineers, but it is a matter of indifference to me whether the empty and pretentious marblery of the Caesars — their rows of statuary, their friezes, their overloaded architraves - is preserved or not. ${ }^{86}$

The engineer or applied scientist is here an artist, but one whose efforts are instrumentally evaluated, in terms of material structures and procedural efficiency, rather than with regards to the expression of truths. Spengler's praise of Roman engineering feats over its plastic arts, with the clear implication that the true artistic expression of cultural spirit lies in the former rather than the latter, further accentuates the aesthetic creativity of the engineer. Spengler also remarks that "in the technical staff of any first-rate engineering works there is more intelligence, taste, character and capacity than in the whole music and painting of present-day Europe." 87 This comment should be viewed, I suggest, not just as a further instance of his argument for the moribund state of contemporary art, but also as an indication that for Spengler aesthetic vitality in Faustian culture is now to be found amongst the technicians.

However, there is an important distinction between technics as an expressive aesthetic form and other such forms. Technics, as befits a non-metaphysical mode of cultural praxis, does not express itself symbolically (in the ideational, intangible sense) but extensively through the material transformation of the world. There is now a "substitution of outer space for inner spiritual space." 88

Strict metaphysics has exhausted its possibilities. The world-city has definitely overcome the land, and now its spirit fashions a theory proper to itself, directed of necessity outward, soulless. Henceforward, we might with some justice replace the word "soul" by the word "brain." And... in the Western "brain" the will to power, the tyrannical set towards the Future and purpose to organize everybody and everything, demands practical expression... ${ }^{89}$

Everything material is to be reorganised to serve the technological Will-to-Power. The Will-to-Infinity that was previously expressed metaphysically and metaphorically will now be actualised in a sustained technological assault on all material limits to the exercise of the Faustian Will.

\footnotetext{
85 Ibid., 43.

86 Ibid., $43-44$.

87 Ibid., 293.

88 Ibid., 360.

${ }^{89}$ Ibid., 367.
} 
It is here in the transformative power of technology that Spengler locates the last vestige of Faustian cultural expression and with it the last existential possibilities for Faustian humanity. Though Spengler warns that the end is nigh for Western culture, he also maintains that in the field of technics there is creative potential that has not yet been exhausted. He states that

The practical side of physics and chemistry has not come close to reaching the limits of its possibilities. Technology's peak in almost all areas has yet to come..$^{90}$

In technology too we find a last living point of contact with the Ur-symbol whose directive has always been felt but now, in the civilizational stage, can be consciously recognized.

Spengler's solution to the crisis of Western civilisation often appears deterministic in that he seems to suggest that one is compelled to embrace a technological mode of existence. However, such an interpretation would overlook the clear existential dimension of Spengler's analysis of technology and his notions of authenticity and existential freedom. For Spengler those who live within the Faustian culture-world share certain structures that both enable and condition their experiential consciousness. The foremost of these is the Ur-symbol. To live a care-full, authentic existence is to take responsibility for the meaning of one's existence and choosing to actualize one's existential possibilities. As Spengler aims to demonstrate with his historical overview of the symbolic development of Faustian culture, with the passage of time the concrete context for actualizing the possibilities one has chosen is subject to change. And as the context changes, the range of action (authentic or otherwise) likewise changes. However, for Spengler, care-full existence always lies in recognizing and living these available possibilities even though no guarantee of eventual success or happiness is or could be given.

Ultimately, for the inhabitants of Faustian civilisation, authentic existence will mean facing death resolutely and without self-deception and choosing to enact their last culturally mandated actions: the expansion of the technological sphere. It is for this reason that Spengler writes

I can only hope that men of the new generation may be moved by this book to devote themselves to technics instead of lyrics, the sea instead of the paintbrush and politics instead of epistemology. Better they could not do. ${ }^{91}$

Spengler does not endorse technics and applied science here because he believes they have some intrinsic value. On Spengler's account existence has no intrinsic meaning and cultures are radically contingent and transient structures. However, humanity has a fundamental need for meaning and meaning, according to Spengler, for the members of a culture is always to be found in fidelity to the Ur-symbol of that culture. If one chooses to live an authentic existence, and for Spengler it is always a choice, then technics is where meaning is to be found. This is the essence of Spengler's conception of existential freedom: to choose to actualize one's existential possibilities from the range of available options in the face of the certainty of one's death. As Spengler puts it, "Life is the process of effecting possibilities [emphasis mine], and for the brain-man there are only extensive possibilities." 92

Existential freedom always lies in choosing one's possibilities from within a range of historically limited options. For Spengler one of the dangers of history is that it lures humanity away from an honest assessment of the possibilities of the present with the siren song of past, and thereby defunct, existential possibilities. He writes

\footnotetext{
90 Ibid., 375.

91 Ibid., 41.

92 Ibid., 37. Emphasis mine.
} 
The first thing that man confronts as inescapable destiny, and that which no thought can grasp and no will alter, is the time and place of his birth: everyone is born into a people, a religion, a position, a time, a culture. Yet with that everything is already decided. Destiny has not let a man be born as a slave in the time of Pericles, or as a knight at the time of the Crusades, but in a working-class home or a villa of the present. If there is some fortune, providence, fate, it is this. History means that Life is ever changing. However, for the individual it is thus and not otherwise. ${ }^{93}$

No individual can escape their own facticity and must construct their own existential project in the concrete circumstances into which they are born. Spengler's historical scepticism is intended to awaken civilizational humanity to the fact that the past is dead and that they must acknowledge the state of the world in which they are at present. One cannot wish oneself into a different time or place.

If Spengler's view on technology appears to be a form of technological determinism it is because he believes that human existence is always determined, in the sense of bounded, by its concrete historical circumstances. "With his [the Faustian individual's] birth is given to him... a circle of possible tasks within which free choice is valid." 94 And, in the present age, those circumstances are technological ones. Consequently, Spengler's notion of existential freedom means "freedom to do, not this or that, but the necessary or nothing." 95 In other words, to choose to actualise current possibilities, or to choose to live a care-less, and thus meaningless, existence. As a result, for Spengler, authenticity in the technological age consists in self-consciously choosing a technological project, i.e. some form of technics understood as a mode of praxis, from amongst the actual range of technological possibilities, whilst constantly cognizant of the contingency and finitude of the culture-world in which this project has meaning.

\section{Technics and Violence}

Despite his reputation as doom-monger and a pessimist, the first volume of The Decline of the West ends on a note of hope. The hope that Spengler dangles before the reader is that of a rapprochement between reason, in the form of technics, and culture, and the possibility of a postponement of the imminent demise of western culture through a late efflorescence of cultural creativity. Reason, long grown cancerous, would be bent once again to the defence of culture. And yet this unexpectedly positive turn in Spengler's narrative merits further analysis, particularly by those who look to his works for guidance or prophecy regarding the resurgence of western civilisation, European culture, or the nation state, depending on one's political preferences. Spengler does indeed hold out the reunion of culture and reason (in the form of technological praxis) as firstly, a genuine possibility, and secondly, a restorative for western culture. However, reflection on the method of restoration and on the culture to be preserved should, I suggest, prompt one to consider carefully the desirability of either.

Turning first to the nature of western culture in its present stage of decline, it is important to note that Spengler does not suggest for a second that the decline can be halted, let alone reversed. Western culture, in its current civilizational state is deathly. The intuitive faith in its cultural symbols is gone, never to return, eroded and ultimately destroyed by rational critique. The inner life of its inhabitants is moribund. Western culture is in a state of spiritual

93 Oswald Spengler, "Pessimismus?," in Reden und Aufsätze (Munich: C.H. Beck'sche Verlagsbuchhandlung, 1937), 70.

94 Oswald Spengler, "Pessimismus?", 71.

${ }^{95}$ Oswald Spengler, The Decline of the West: Form and Actuality, 39. 
exhaustion and thus, though the need for cultural meaning is felt, it lacks the resources to fashion them anew. In civilisation "mankind loses its spiritual fruitfulness forever, and building takes the place of begetting." 96 By this Spengler indicates that the life of inner creativity is closed to the last of the west, and only feats of extensive, mechanical praxis are open to them. The present inhabitants of Faustian culture are themselves the products of the tyranny of reason. In the "civilised man the tragic world-feeling succumbs to the mechanising intellect". ${ }^{97}$ It is an age of "cold matter-of-fact", "scientific irreligion" and "keen and cold intelligence." 98 Faustian culture is populated by the children of the world-as-nature, rational, calculating, soulless and sterile. Mechanical themselves, Faustian humanity can only act in mechanical ways. This is the level of Faustian culture that Spengler's rapprochement with reason through technics will preserve, that of automatons in a museum exhibit, an imitation of cultural life.

The means by which these cultural petrifacts will be preserved for another few centuries is likewise problematic. On Spengler's account, the only avenues for progressive activity that remain available to the "brain-men" of the Faustian west are "extensive possibilities." "By progressive in this context I mean activities that add to the cultural-totality, as opposed to simply maintain pre-existing cultural forms. However it should be understood that this progress is purely quantitative and material. It does not represent any sort of growth of the culture-organism, but a calcified expansion of the material 'shell' of the culture. And the means by which it will effect this growth is by harnessing the world-spanning powers of modern technics to this expansive project. This is the last echo of the Ur-symbol's symbolic imperative, to actualise the will-to-infinity in the world around, but realised in entirely external, materialist terms. The forces of modern technics give western civilisation unprecedented means for the exercise of effective power, and Spengler's cultural 'renewal' entails making full use of these powers to express the will-to-infinity as it is currently capable of being construed by the modern intellect, "sceptical, practical, artificial."100 Though Spengler, in the first volume of The Decline, is rather circumspect in drawing out the implications of his proposal, it is clear enough that this will entail the exercise of power to facilitate the exercise of power, a reordering of all that lies within the technical reach of Faustian culture in order to express the Will of the west and to put things in readiness for subsequent use. A rational restructuring of the world through force as an end in itself.

Spengler declares that there is "grandeur also in the realizations of powerful intelligences, in the energy and discipline of metal-hard natures, in battles fought with the coldest and most abstract means." 101 And yet it is clear that the delay in the demise of western culture is to be purchased by means of violence. Spengler envisions a process whereby the social chaos caused by the corrosive effect of critical reason on social bonds is to be overcome through the imposition of order. Political, economic and technological power is to be exercised internally to compel the inchoate Faustian mass to direct itself outwards, to mobilise its forces in order to exercise its power externally. Spengler's stay of execution is a cultural tragedy, whereby a culture buys the right to feign health through internal and external violence carried out on a mass-scale using the most rational and powerful means. In the second volume of The Decline, though it represents a marked alteration in Spengler's thought from that of the

\footnotetext{
96 Ibid., 359.

97 Ibid., 159.

98 Ibid., 33.

99 Ibid., 37.

100 Ibid., 353-354.

101 Ibid., 38.
} 
first volume, Spengler is unambiguous in his interpretation of what this rapprochement of culture and reason will entail: war.

In these wars of theirs for the heritage of the whole world, continents will be staked, India, China, South Africa, Russia, Islam called out, new technics and tactics played and counterplayed. The great cosmopolitan foci of power will dispose at their pleasure of smaller states - their territory, their economy and their men alike - all that is now merely province, passive object, means to end, and its destinies are without importance to the great march of things. We ourselves, in a very few years, have learned to take little or no notice of events that before the War would have horrified the world; who to-day seriously thinks about the millions that perish in Russia? ${ }^{102}$

The people who will perish in this culturally-salvific bloodletting are rendered invisible, a collection of entities in the world-as-nature. Spengler refers to the victims of his culture's expansive trajectory as passive objects, a means to an end. Considering his own culture, he states that, "The expansive tendency is a doom, something daemonic and immense, which grips, forces into service, and uses up the late mankind of the world-city stage, willy-nilly, aware or unaware." 103 Here too the people who constitute Faustian culture are reduced to pure resource, to be forced into service and used up. Spengler's hope for cultural preservation is vampiric. And in reducing the living inhabitants of a culture to mere things with a utilityvalue, he reveals himself as a product of the deathly, mechanising rationality that he spent both volumes of his masterwork decrying. Lewis Mumford best captured the horrific irony of Spengler's position:

Was there no way for life... to reassert itself? Spengler answered Yes: by brutality and conquest. The sole outlet open to the victims of civilisation was to replenish their barbarism and consummate their will-to-destruction. ${ }^{104}$

\section{Conclusion}

Oswald Spengler, in his 1918 The Decline of the West, links western culture's imminent demise with the triumph of Enlightenment rationality, as exemplified by the work of Immanuel Kant. Spengler associates Enlightenment rationality with cosmopolitanism, democracy and other forces that have eroded the foundations of living culture and brought about the West's terminal stage, that of civilisation. Though Spengler is with some justification portrayed as an irrationalist, his critique of the elevation of universal reason does not entail the rejection of reason, particularly with regards to its application in the forms of science and technology.

Spengler argues that reason is not in and of itself opposed to the mythical, creative powers of culture. Rather, on Spengler's account, reason is itself an expression of western culture which, in its scientific form, comes closest to a pure expression of the metaphysical structure of cultural reality. However rather than serving life, Spengler maintains, reason has been elevated above other forms of cultural expression and its spatial logic made dominant over the temporal logic of living beings. Cut off from its source in living culture, Spengler suggests, reason becomes violently hostile to life. It dismembers the living unity of culture and imposes conceptual and material constraints upon life that aim to reduce it to a deathly, static state.

\footnotetext{
102 Oswald Spengler, The Decline of the West: Perspectives of World-History (New York: Alfred A. Knopf, 1928), 429.

103 Oswald Spengler, The Decline of the West: Form and Actuality, 37.

104 Lewis Mumford, Interpretations and Forecasts: 1922-1972 (New York: Harcourt Brace Jovanovich, 1979), 220.
} 
Spengler's Decline, however, does more than simply lament the human condition in its terminal state of spiritual and social decay. It also offers a means by which to reverse the fatal effects of the tyranny of reason and reknit the social body, for a time at least. Spengler offers, as a solution for the inwardly directed violence of rational civilisation, the curative of outwardly directed violence. Reason is to be reunited with the last remnants of the symbolic structure that underpinned western culture. Reason is to serve myth, as it did in the dawn of the culture, one last time. Reason, in the form of the applied sciences, has presented western culture with technics of unprecedented power. It is through these means, Spengler argues, that it will express its cultural vision: a will to infinite expansion expressed not through religious experience or artistic creation, but through technological violence.

Contrary to his popular perception as a prophet of inevitable doom, Spengler's Decline does more than simply catalogue the spiritual sickness of his age and foretell the end of the west. Rather it puts forward the violence of extensive power and expansive politics as a means, not of defending western culture, but of revivifying it. In effect, he proposes employing mechanical means to preserve the cultural organism. For Spengler it is the violence of reason against culture that has poisoned the west and it is only the use of that violence in the service of western culture that can save it. The violence that has fractured cultural unity calls forth a restorative violence. It is this notion of restorative violence, I suggest, that renders Spengler's sudden resurgence of popularity in popular discourse particularly problematic. For the recourse to violence as the (temporary) salvation of western culture itself points back to the debased state of western civilisation. The spiritual aridity of its denizens is, by Spengler's own account, incurable and the very fact that Spengler identifies expansive technological violence as its only remaining mode of cultural expression is itself a damning indictment of Faustian culture's right to exist, let alone prolong that existence.

\section{Acknowledgments}

I would like to thank Professor David Spurrett of the School of Religion, Philosophy and Classics at the University of KwaZulu-Natal who commented on an earlier version of this paper.

\section{References}

Ellul, Jacques. The Technological Society. New York: Alfred A. Knopf, 1964.

Frye, Northrop. "The Decline of the West.” Daedalus 103/ 1 (1974): 1-13.

Habermas, Jurgen. Knowledge and Human Interests. Cambridge: Polity Press, 1987.

Herf, Jeffrey. Reactionary Modernism: Technology, culture and politics in Weimar and the Third Reich. Cambridge: Cambridge University Press, 1984.

Hughes, H. Stuart. Oswald Spengler: A Critical Estimate. New York: Charles Scribner's Sons, 1952.

Huizinga, Johan H. 'Two Wrestlers with the Angel." In Dutch Civilisation in the Seventeenth Century (London: Collins, 1968), 158-218.

Jaspers, Karl. 1969. Philosophy Volume 2. Chicago: Chicago University Press, 1969.

Merlio, Gilbert. 'Spengler und die Technik." In Spengler Heute, edited by Peter Christian Ludz, 100-122. Munich: Verlag C.H. Beck, 1980.

Marcuse, Herbert. One Dimensional Man. London: Routledge Kegan Paul, 1964.

Mumford, Lewis. The Myth of the Machine. New York: Harcourt Brace, 1967. Interpretations and Forecasts: 1922-1972. New York: Harcourt Brace Jovanovich, 1979. 
Peach, Filiz. Death, "Deathlessness" and Existenz in Karl Jaspers' Philosophy. Edinburgh: Edinburgh University Press, 2008.

Scheler, Max. Selected Philosophical Essays. Evanston: Northwestern University Press, 1973. Spengler, Oswald. The Decline of the West: Form and Actuality. New York: Alfred A. Knopf, 1926.

. The Decline of the West: Perspectives of World-History. New York: Alfred A. Knopf, 1928. . "Pessimismus?" In Reden und Aufsätre, 63-79. Munich: C.H. Beck'sche Verlagsbuchhandlung, 937.

Swer, Gregory. "Oswald Spengler and Martin Heidegger on Modern Science, Metaphysics and Mathematics." Idealistic Studies 47/1 \& 2 (2017): 1-21.

."Timely Meditations?: Oswald Spengler's Philosophy of History Reconsidered.” Prolegomena 17/2 (2018):137-154.

"Longing, Dread and Care: Spengler's Account of the Existential Structure of Human Experience.” Journal of the British Society for Phenomenology 51:1 (2020): 71-87. " "Technology and the end of western civilisation: Spengler's and Heidegger's histories of life/Being." Indo-Pacific Journal of Phenomenology 19/1, (2019) : 3-12.

Vaihinger, Hans. The Philosophy of As If. Translated by C. K. Ogden. London: Kegan Paul, Trench, Trubner \& Co., 1935. 